\title{
Lactation Curve Pattern and Prediction of Milk Production Performance in Crossbred Cows
}

\author{
Suresh Jingar, ${ }^{1,2}$ R. K. Mehla, ${ }^{1}$ Mahendra Singh, ${ }^{1}$ and A. K. Roy ${ }^{1}$ \\ ${ }^{1}$ National Dairy Research Institute, Karnal 132 001, India \\ ${ }^{2}$ KVK, Chittorgarh, Rajasthan 312001, India \\ Correspondence should be addressed to Mahendra Singh; chhokar.ms@gmail.com
}

Received 29 May 2014; Accepted 24 June 2014; Published 13 July 2014

Academic Editor: Masanori Tohno

Copyright (C) 2014 Suresh Jingar et al. This is an open access article distributed under the Creative Commons Attribution License, which permits unrestricted use, distribution, and reproduction in any medium, provided the original work is properly cited.

Data pertaining to 11728 test-day daily milk yields of normal and mastitis Karan Fries cows were collected from the institute herd and divided as mastitis and nonmastitis and parity-wise. The data of lactation curves of the normal and mastitis crossbred cows was analyzed using gamma type function. FTDMY in normal and mastitis cows showed an increasing trend from TD-1 to TD-4 and a gradual decrease $(P<0.01)$ thereafter until the end of lactation $(\mathrm{TD}-21)$ in different parities. The FTDMY was maximum (peak yield) in the fourth parity. Parity-wise lactation curve revealed a decrease in persistency, steeper decline in descending slope (c), and steeper increase in ascending slope $(b)$ from 1st to 5 th and above parity. The higher coefficient of determination $\left(R^{2}\right)$ and lower root mean square error (RMSE) indicated goodness and accuracy of the model for the prediction of milk prediction performance under field conditions. Clinical mastitis resulted in a significantly higher loss of milk yield $(P<0.05)$. The FTDMY was maximum $(P<0.05)$ in the fourth parity in comparison to the rest of parity. It is demonstrated that gamma type function can give the best fit lactation curve in normal and mastitis infected crossbred cows.

\section{Introduction}

Lactation curve provides valuable information about the pattern of milk production during lactation. It also depicts summary of the pattern of milk yield determined by the biological efficiency of the cow [1]. The cost of milk production depends to a large extent on the persistency of lactation, that is, the rate of decline in production after peak milk yield. High persistency is associated with a slow rate of decline in milk production, whereas low persistency is associated with a rapid rate of decline in milk yield. In general declining rate of milk production is about $7 \%$ per month after the peak yield [2]. Estimates of heritabilities for milk yield and persistency traits in HF cows have been reported $[3,4]$. The lactation curve models have been used to predict the milk yield at any point of the lactation [5, 6]. This property of the model can prove beneficial in case of incomplete lactation records. Various models have been tried by different researchers to fit the lactation curve in indigenous as well as exotic cattle [7-10]. Further getting the test-day milk yield information from the field conditions is not easy and there is every chance of missing the data due to certain inevitable circumstances. In such case mathematical models may prove beneficial for prediction of milk production performance using. In view of this the lactation curve was composed for the normal vis-à-vis mastitis cows using gamma type function during different parity to find out the accuracy of model in predicting the milk yield with minimum error in normal and mastitis crossbred cows.

\section{Materials and Methods}

The data on 11728 fortnightly test-day milk yields (FTDMYs) of 733 Karan Fries cows for a period of 12 years (2000-2011) was collected from livestock farm of National Dairy Research Institute, Karnal, India. The climate of the farm is subtropical in nature with the lowest temperature reaching $2^{\circ} \mathrm{C}$ during winter and the highest temperature up to $45^{\circ} \mathrm{C}$ in the summer months. The annual rainfall is about 760 to $960 \mathrm{~mm}$, out of which most of the rainfall is received during the months of July and August. The relative humidity ranges from $41 \%$ to $85 \%$. The amount of milk recorded in 24 -hour duration on 


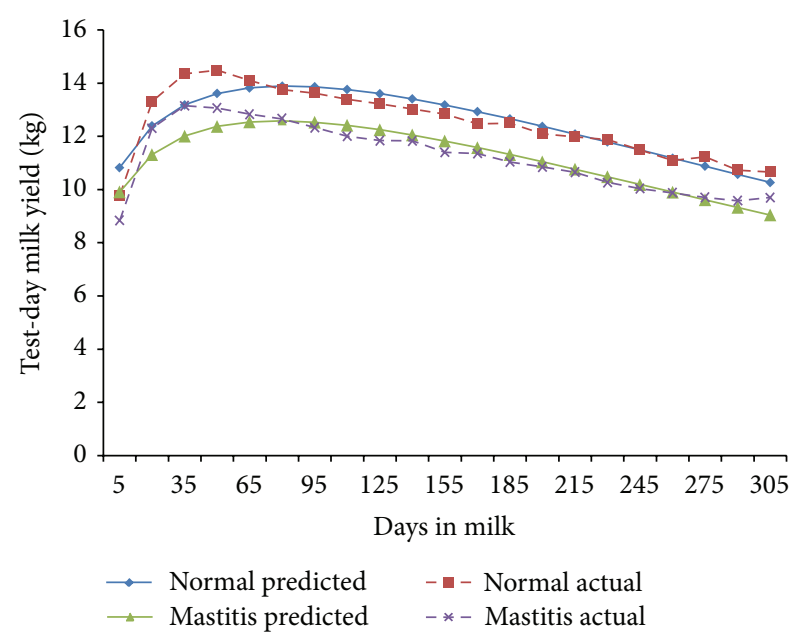

FIGURE 1: Comparison of the actual and predicted FTDMY of normal and mastitic Karan Fries cows in the first lactation.

any particular day is called the test-day (TD) milk yield and is expressed in kilograms. The fortnightly test-day intervals of 15 days were considered starting from days $5,20,35,50$, $65,80,95,110,125,140,155,170,185,200,215,230,245,260$, 275,290 , and 305 of lactation. Twenty-one (21) fortnightly test-day milk yield (FTDMY) records were considered per lactation (from the 6th to the 305th day of lactation). The data was grouped as mastitis (cows suffering from clinical mastitis) and nonmastitis (normal cows). Statistical analysis of data was carried out using gamma type function [11] with the following equation:

$$
Y_{t}=a t^{b} e^{-c t},
$$

where $Y_{t}$ is the average daily yield in the $t$ th fortnight, $a$ is the initial milk yield after calving, $b$ is the ascending slope parameter up to the peak yield, and $c$ is the descending slope parameter.

The constants were derived by solving the above equation after transformation on the log scale:

$$
\ln \left(Y_{t}\right)=\ln (a)+b \ln (t)-c t .
$$

The milk yield up to week " $t$ " is given by $Y_{t}=$ $a \int_{0 \rightarrow 1} t^{b} \exp (-c t) d t$.

\section{Results}

The fortnightly test-day milk yield was less in TD-1 (9.78 \pm $0.29 \mathrm{~kg} / \mathrm{d})$ and increased $(P<0.01)$ gradually to attain peak in TD-3 and TD-4 (14.34 \pm 0.38 and $14.48 \pm 0.37 \mathrm{~kg} / \mathrm{d})$ in normal cows; however, in mastitis cows, the peak milk yield was attained in TD-3 (13.15 $\pm 0.37 \mathrm{Kg} / \mathrm{d})$ and was maintained only for this period (Figure 1). The cows of both of the groups exhibited a steady decline $(P<0.01)$ in milk yield with increase in fortnights of lactation. In general the fortnightly test-day milk yield increased till TD3 and declined steadily with advancement of lactation. In the second parity the FTDMY showed an increasing trend

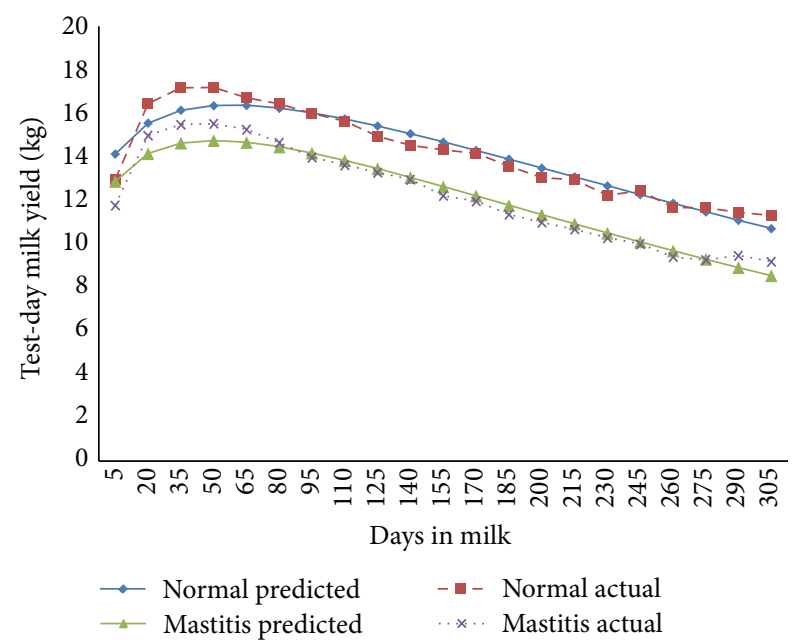

FIgURE 2: Comparison of the actual and predicted FTDMY of normal and mastitic Karan Fries cows in the second lactation.

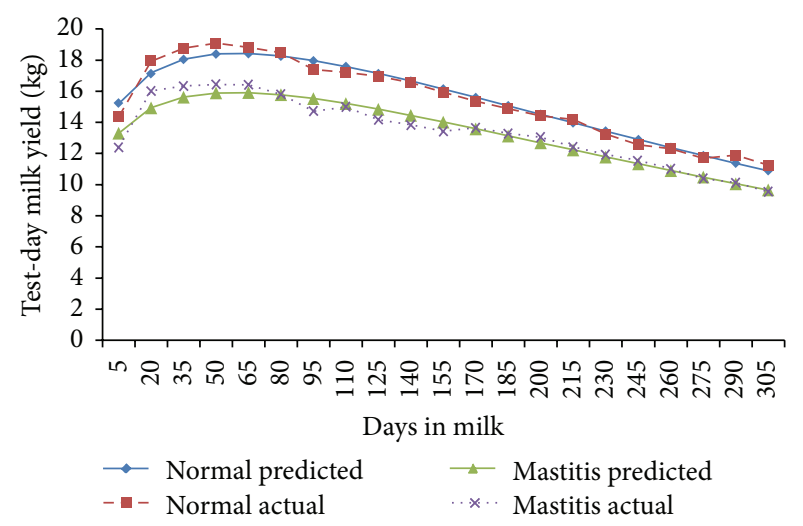

FIgURE 3: Comparison of the actual and predicted FTDMY of normal and mastitic Karan Fries cows in the third lactation.

from TD-1 to TD-4 and decreased thereafter gradually in both of the groups. A minimum FTDMY of $11.31 \pm 0.39 \mathrm{~kg} / \mathrm{d}$ and $9.18 \pm 0.44 \mathrm{~kg} / \mathrm{d}$ and a maximum FTDMY of $17.19 \pm$ $0.44 \mathrm{~kg} / \mathrm{d}$ and $15.53 \pm 0.46 \mathrm{~kg} / \mathrm{d}$ were observed on TD- 4 in both of the groups (Figure 2). The minimum FTDMY ranged from $11.25 \pm 0.46 \mathrm{~kg} / \mathrm{d}$ to $9.55 \pm 0.47 \mathrm{~kg} / \mathrm{d}$ in TD-21 and the maximum FTDMY of $19.08 \pm 0.53 \mathrm{~kg} / \mathrm{d}$ and $16.44 \pm 0.47 \mathrm{~kg} / \mathrm{d}$ was observed in TD-4 in normal and mastitis KF cows. However an increase in FTDMY was observed from $14.36 \mathrm{~kg}$ and $12.34 \mathrm{~kg}$ in TD-1 to a peak yield of $20.50 \pm 0.59 \mathrm{~kg} / \mathrm{d}$ in TD-4 and $17.63 \mathrm{~kg} / \mathrm{d}$ in TD-3 which subsequently declined $(P<0.05)$ to $10.50 \pm 0.54 \mathrm{~kg} / \mathrm{d}$ and $9.54 \pm 0.54 \mathrm{~kg} / \mathrm{d}$ in TD21 in normal and mastitis KF cows (Figure 3). The FTDMY milk yield in the 4th parity was maximum in comparison to the first, second, and third parity in both normal and mastitis cows (Figure 4, Table 2). An increase in milk production was observed up to the 4th fortnight and milk productions decreased $(P<0.01)$ during the 5th parity in normal cows. In mastitis cows increase in milk yield was noticed during the first three fortnights and milk production decreased subsequently $(P<0.05)$ until the end of lactation (Figure 5$)$. 
TABle 1: Parity-wise lactation curve parameters (gamma type function) for prediction of fortnightly test-day milk yield (kg) in Karan Fries crossbred cows.

\begin{tabular}{|c|c|c|c|c|c|c|c|c|c|c|}
\hline \multicolumn{11}{|c|}{ Karan Fries cows } \\
\hline \multirow{2}{*}{ Parameters } & \multicolumn{2}{|c|}{ 1st parity } & \multicolumn{2}{|c|}{ 2nd parity } & \multicolumn{2}{|c|}{ 3rd parity } & \multicolumn{2}{|c|}{ 4th parity } & \multicolumn{2}{|c|}{ 5th and above parity } \\
\hline & $\begin{array}{c}\text { Normal } \\
\text { cows }\end{array}$ & $\begin{array}{c}\text { Mastitis } \\
\text { cows }\end{array}$ & $\begin{array}{c}\text { Normal } \\
\text { cows }\end{array}$ & $\begin{array}{c}\text { Mastitis } \\
\text { cows }\end{array}$ & $\begin{array}{c}\text { Normal } \\
\text { cows }\end{array}$ & $\begin{array}{c}\text { Mastitis } \\
\text { cows }\end{array}$ & $\begin{array}{c}\text { Normal } \\
\text { cows }\end{array}$ & $\begin{array}{c}\text { Mastitis } \\
\text { cows }\end{array}$ & $\begin{array}{c}\text { Normal } \\
\text { cows }\end{array}$ & $\begin{array}{c}\text { Mastitis } \\
\text { cows }\end{array}$ \\
\hline$a$ & 11.28 & 10.35 & 14.78 & 13.57 & 16.08 & 14.03 & 16.45 & 14.42 & 15.09 & 13.57 \\
\hline$b$ & 0.254 & 0.255 & 0.202 & 0.213 & 0.259 & 0.243 & 0.333 & 0.281 & 0.358 & 0.310 \\
\hline$c$ & 0.041 & 0.043 & 0.045 & 0.053 & 0.056 & 0.053 & 0.072 & 0.063 & 0.070 & 0.070 \\
\hline Persistency & 54.34 & 51.41 & 41.96 & 35.30 & 37.59 & 38.50 & 33.51 & 34.82 & 36.56 & 33.67 \\
\hline Fortnight of PMY & 6.15 & 5.88 & 4.53 & 4.02 & 4.61 & 4.58 & 4.64 & 4.49 & 5.07 & 4.55 \\
\hline Fortnightly PMY (kg) & 13.89 & 12.58 & 16.39 & 18.04 & 18.44 & 15.93 & 19.67 & 16.61 & 18.85 & 15.94 \\
\hline$R^{2}$ value $(\%)$ & 84.88 & 83.93 & 93.03 & 94.87 & 97.43 & 95.42 & 98.18 & 95.52 & 94.84 & 97.68 \\
\hline RMSE (kg) & 0.08 & 0.11 & 0.12 & 0.11 & 0.09 & 0.11 & 0.10 & 0.13 & 0.16 & 0.09 \\
\hline
\end{tabular}

( $a$ is the initial milk yield after calving; $b$ is the ascending slope parameter up to peak yield; $c$ is the descending slope parameter; RMSE is the root mean square error; $R^{2}$ is the coefficient of determination of variation; and PMY is the peak milk yield).

TABLE 2: Overall actual and predicted milk yield showing accuracy of the model in crossbred cows.

\begin{tabular}{|c|c|c|c|c|c|c|}
\hline \multirow{2}{*}{ Parity } & \multicolumn{3}{|c|}{ Normal cows } & \multicolumn{3}{|c|}{ Mastitis cows } \\
\hline & Act. & Pred. & Accuracy \% & Act. & Pred. & Accuracy \% \\
\hline 1 & $12.47^{\mathrm{a}}$ & $12.46^{\mathrm{a}}$ & 99.02 & $11.20^{\mathrm{a}}$ & $11.19^{\mathrm{a}}$ & 99.90 \\
\hline 2 & $14.13^{\mathrm{b}}$ & $14.12^{\mathrm{b}}$ & 99.04 & $12.20^{\mathrm{b}}$ & $12.18^{\mathrm{b}}$ & 99.02 \\
\hline 3 & $15.39^{c}$ & $15.39^{c}$ & 99.09 & $13.40^{c}$ & $13.39^{\mathrm{c}}$ & 99.04 \\
\hline 4 & $15.69^{c}$ & $15.68^{\mathrm{c}}$ & 99.06 & $13.55^{\mathrm{c}}$ & $13.55^{\mathrm{c}}$ & 100.00 \\
\hline 5 and above & $15.32^{c}$ & $15.30^{\mathrm{c}}$ & 99.90 & $12.79^{\mathrm{d}, \mathrm{b}}$ & $12.79^{\mathrm{d}, \mathrm{b}}$ & 100.00 \\
\hline
\end{tabular}

Superscripts $\mathrm{a}, \mathrm{b}$, and $\mathrm{c}$ differ significantly $(P<0.05)$ in row and column.

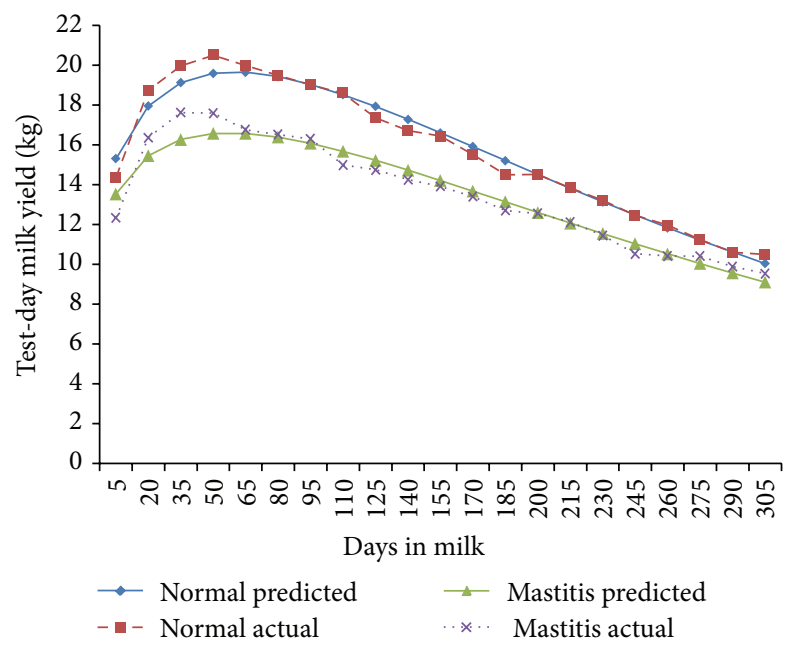

Figure 4: Comparison of the actual and predicted FTDMY of normal and mastitic Karan Fries cows in the fourth lactation.

Estimation of lactation curve parameters for prediction of fortnightly test-day milk yield.

The parity-wise estimated lactation curve parameters for FTDMY indicated higher average initial milk yield (a) in normal cows as compared to mastitis cows in different parities (Table 1). The peak milk yield was observed in the 4 th parity $(16.45 \mathrm{~kg}$ and $14.42 \mathrm{~kg})$ while minimum yield

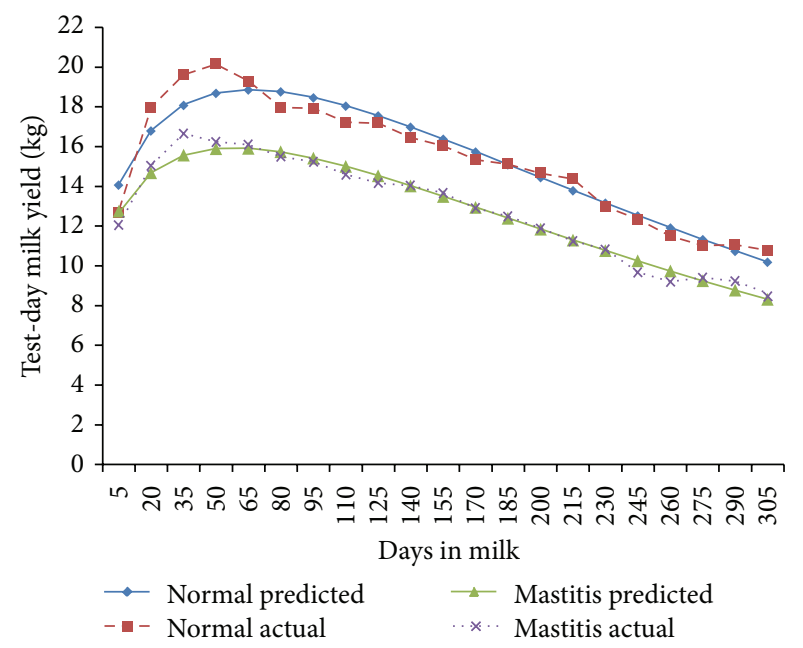

FIGURE 5: Comparison of the actual and predicted FTDMY of normal and mastitic Karan Fries cows in the fifth and above lactation.

was observed in the 1st parity in both normal and mastitis cows (11.28 versus $10.35 \mathrm{~kg} / \mathrm{d})$. Lactation curve parameter of ascending slope parameter up to peak yield $(b)$ was similar in both the groups in the 1st parity, declined in the 2nd parity, and increased in the subsequent parities. The descending slope parameter $(c)$ was lower in the 1st parity $(0.041)$ and 
higher in the 4 th parity $(0.072)$ in normal cows, but, in mastitis cows, it was minimum in the 1st parity (0.043) and maximum in the 5 th and above parity $(0.070)$. Further higher persistency of lactation was observed in the 1st parity (54.34 and 51.40) which declined till the 5th and above parity in all of the cows. The fortnights of peak milk yield ranged from averagely 4.53 to 6.15 fortnights in normal cows and from 4.49 to 5.88 fortnights in mastitis cows. The cows in the first parity took more time (fortnight) to attain peak yield in comparison to subsequent parity; however, peak milk yield increased $(P<0.05)$ with increase in number of parity in both of the groups. The peak yield was minimum in the 1st parity $(13.89 \mathrm{~kg} / \mathrm{d}$ and $12.58 \mathrm{~kg} / \mathrm{d})$ and maximum in the 4 th parity $(19.67 \mathrm{~kg} / \mathrm{d}$ and $16.61 \mathrm{~kg} / \mathrm{d})$ in normal and mastitis cows. The coefficient of determination of variation $\left(R^{2}\right)$ ranged from $84.88 \%$ to $98.18 \%$ in normal cows and from $83.93 \%$ to $97.68 \%$ in mastitis cows during different parities. The RMSE value was minimum in the $3 \mathrm{rd}$ parity $(0.09 \mathrm{~kg})$ and maximum in the 5 th and above parity $(0.16 \mathrm{~kg})$ in normal cows; however, in mastitis cows RMSE was minimum in the 5 th and above parity $(0.09)$ and maximum in the 4 th parity $(0.13 \mathrm{~kg})$.

\section{Discussion}

The pattern of change in the FTDMY observed in this study was in agreement with the earlier reports in normal cattle and buffaloes [12-17]. However comparable literature on fortnightly test-day milk yield (FTDMY) and fortnightly average daily milk yield (FADMY) in mastitis crossbred KF cows is scanty. The peak milk yield attained during the $3 \mathrm{rd}$ and 4th fortnights in both of the groups corroborates with the values reported earlier in cows $[10,18,19]$. The trend in FTDMY in both of the groups suggested that peak yield duration is not affected by incidence of mastitis in spite of significant decline in milk yield $(P<0.01)$. The lower initial milk yield $(a)$ in the first parity and an increasing trend in subsequent parity have also been reported in normal KF cows [10] and Butana dairy cows [20]. Many research findings indicated an increase in initial milk yield value with increase of parity order and the highest initial milk yield reaches the 5th lactation in Friesian and Ayrshire crossbred and KF cows [21-25]; however, such trend was evident up to the 4th parity in this study. The lower initial yield, peak milk yield, and greater persistency in the first parity than the subsequent parity in KF cows as observed in this study corroborate earlier reports [6,26-31]. This is expected because lactation curves of the first parity are characterized by a less peak milk production and a greater persistency in ruminants $[11,20,24]$. The decline in persistency of lactation with increase in parity order is attributed to age factor as older animals start their lactation at a higher level and had a rapid rate of decline in milk production due to regression of alveolar cells with advancement in age. Further, firstcalving animals have less body weight and maturation of mammary tissue is still active, which counterbalances decline in milk production [32]. During the first lactation, animal encounters unfamiliar situations, including the atmosphere of the milking parlor, presence of dairy farmer, and the milking procedures [24]. Thus variation in the initial milk yield in different parities could be due to addition of more number of alveolar cells (secretory cells) at each successive pregnancy which reach their maximum numbers at about the 5th calving and diminish gradually thereafter [33].

The value of ascending slope parameter up to peak yield (b) in the present study was lower than reported earlier in different parity of Friesian and Ayrshire crossbred cows due to difference in milk yield of cows, management practices followed in a farm, and breed difference [33]. The similar pattern of increase in constant " $b$ " with advancement of parity in both of the groups was also reported in Butana dairy cows [23], HF cows [34], and crossbred cows [35]. However, value of parameter " $b$ " was lower than the reported values in HF, KF, and Sahiwal cows $[10,21,36]$ than the value of parameter " $b$ " observed in our study. The higher descending slope parameter $(c)$ observed in this study was in agreement with the findings of previous reports $[33,35]$ in crossbred cows and was lower than reported values in Sahiwal cows [36] and Holstein cows [21]. The more flat shape of parameter " $c$ " in the first parity than the rest of the parities indicated better utilization of feeds and less susceptibility of cows to metabolic and reproductive disorders [37]. The marginal differences in parameters " $a$," " $b$," and " $c$ " in mastitis cows rather than the normal ones were due to disturbed milk secretion and apoptosis of mammary secretory cells that is solely responsible for the decline in milk yield after peak lactation $[38,39]$. It has been found that turn of lactation curve was unimportant on the level of persistency of lactation in Brown Swiss cows [40]. Further occurrence of atypical shapes of lactation curve characterized by the absence of the lactation peak varied from 25 to $42 \%$ [41]. Previous report also supports the fact that peak yield is lower in the first parity and increases in subsequent parity [33]. The lower initial and peak milk yield in the first parity and more time to attain peak yield in the first parity than the remaining parities were in agreement with previous reports in Norwegian mastitis cows [25, 33]. It has been found that Holstein $\mathrm{x}$ Zebu cows require 71 days to reach peak yield, which was less than the predicted 6.15 fortnights observed in crossbred cows [42]. However, predicted fortnightly peak milk yield was nonsignificantly different in both mastitis and normal cows (5.88 versus $6.15 \mathrm{~kg} / \mathrm{d}$ ). Further moderate to high heritability estimates for different lactation curve shape parameters suggest that these traits can be included in selection schemes [43]. It has been reported that the milk secretory tissue requires more time for peak activity in primiparous cows than multiparous cows due to reduced udder size, less digestive capacity, and directs partitioning of nutrients $[24,41]$. The high persistency is associated with a slow rate of decline in milk yield after peak production, while low persistency is associated with a rapid rate of decline in milk yield due to less feed intake [44]. Further persistent lactations are characterized by lower peak yield [37] and reduced metabolic stress in early lactation [45]. The high score of goodness of fit ( $R^{2}$ value) of gamma type function corroborates the earlier reports in cows $[10,19,21,22,36]$. The gamma function has been reported as the best model because of the small error variance and high determination coefficient 
[4]. From gamma function, approximately one third (31.28\% percent) of lactation curves were named atypical. Atypical curve percentages were found as follows: $44.19 \%$ downhill, 45.08\% concave, $7.32 \%$ LnA negative, and 3.39\% C negative. Further first lactation goodness of fit in normal and mastitis cows indicated more fitness of the model in KF crossbred cows as evident from low RMSE value. The latter confirms accuracy of gamma function model to predict milk yield of mastitis cows also [11, 46]. The similar value of $R^{2}$ in normal and mastitis cows further indicated accuracy of model level [31]. The similar RMSE values in mastitis and normal KF cows during different parities also support this fact.

\section{Conclusion}

The lactation curve parameters for fortnightly test-day milk yield exhibited similar trend in normal and mastitis infected cows by attaining peak milk yield in the 3rd and 4th TD followed by a gradual decline in milk yield till the end of lactation. The steeper decline in descending slope $(c)$ and increase in initial FTDMY due to steeper rise in ascending slope from the 1st parity onwards could be used as a marker of persistency during different parities in cows. Further, higher $R^{2}$ and lower RMSE confirm the validity of gamma type function in predicting the milk yields in cows suffering from mastitis.

\section{Conflict of Interests}

The authors declare that there is no conflict of interests regarding the publication of this paper.

\section{Acknowledgments}

The authors are thankful to Director, N.D.R.I., Karnal, and The Head, Dairy Cattle Breeding Division, NDRI, Karnal, for providing the necessary facilities for the study. The help rendered by the Livestock Record Unit in providing the data for data analysis is greatly acknowledged.

\section{References}

[1] T. A. Scott, B. Yandell, L. Zepeda, R. D. Shaver, and R. T. R. Smith, "Use of Lactation curves for analysis of milk production data," Journal of Dairy Science, vol. 79, no. 10, pp. 1885-1894, 1996.

[2] D. Val-Arreola, E. Kebreab, J. Dijkstra, and J. France, "Study of the lactation curve in dairy cattle on farms in central Mexico," Journal of Dairy Science, vol. 87, no. 11, pp. 3789-3799, 2004.

[3] A. Kaygısız, G. Bakır, and S. M. Yener, "Estimates of phenotypic and genetic parameters of lactation persistency in Holstein cows," Journal of Veterinary and Animal Sciences, vol. 19, no. 4, pp. 259-263, 1995 (Turkish).

[4] H. Orhan and A. Kaygisiz, "Comparison of different lactation curve models for Holstein cattle," Hayvansal Üretim, vol. 43, no. 1, pp. 94-99, 2002.

[5] L. Pérochon, J. B. Coulon, and F. Lescourret, "Modelling lactation curves of dairy cows with emphasis on individual variability," Animal Science, vol. 63, no. 2, pp. 189-200, 1996.
[6] N. Macciotta, D. Vicario, and A. Cappio-Borlino, "Detection of different shapes of lactation curve for milk yield in dairy cattle by empirical mathematical models," Journal of Dairy Science, vol. 88, no. 3, pp. 1178-1191, 2005.

[7] G. C. Gahlot, R. S. Gahlot, and L. K. Jairath, "Pattern of lactation curve in Rathi cattle," Indian Journal of Animal Science, vol. 58, no. 9, pp. 1112-1114, 1998.

[8] S. Cilek and I. Keskin, "Comparison of six different mathematical models to the lactation curve of simmental cows reared in Kazova state farm," Journal of Animal and Veterinary Advances, vol. 7, no. 10, pp. 1316-1319, 2008.

[9] Z. Guo and H. H. Swalve, "Modelling of the lactation curve as a sub-model in the evaluation of test day records," in Proceedings of Interbull Meeting, Prague, No. 11, Interbull Bulletin, Uppsala, Sweden, 1995.

[10] B. Rashia, Genetic evaluation of lactation curve in Karan Fries cattle [Ph.D. thesis], NDRI Deemed University, Karnal, India, 2010.

[11] P. D. P. Wood, "Factors affecting the shape of the lactation curve in cattle," Journal of Animal Production, vol. 11, pp. 307-331, 1967.

[12] E. D. Ilatsia, T. K. Muasya, W. B. Muhuyi, and A. K. Khai, "Genetic and phenotypic parameters and annual trends for milk production and fertility traits of the Sahiwal cattle in semi arid Kenya," Tropical Animal Health and Production, vol. 39, no. 1, pp. 37-48, 2007.

[13] G. Bilal, M. S. Khan, I. R. Bajwa, and M. Shafiq, "Genetic control of test-day milk yield in Sahiwal cattle," Pakistan Veterinary Journal, vol. 28, no. 1, pp. 21-24, 2008.

[14] T. Humberto, F. C. M. Mario, A. D. O. Joao, E. L. F. Lenira, L. F. L. Andre, and G. D. A. Lucia, "Test-day milk yield as a selection criterion for dairy buffaloes," Genetics and Molecular Biololgy, vol. 31, no. 3, pp. 108-112, 2008.

[15] L. Kokate, Genetic evaluation of Karan fries sires based on test-day milk yield records [M. S. Thesis], NDRI (Deemed University), Karnal, India, 2009.

[16] D. Monalisa, R. S. Gandhi, T. V. Raja, A. Singh, and G. K. Sachdeva, "Influence of certain non-genetic factors on test day milk records in Sahiwal cattle," Indian Journal of Dairy Science, vol. 63, no. 6, pp. 504-506, 2010.

[17] R. J. Pereira, R. S. Verneque, P. S. Lopes et al., "Milk yield persistency in Brazilian Gyr cattle based on a random regression model," Genetics and Molecular Research, vol. 11, no. 2, pp. 15991609, 2012.

[18] V. Vohra, Studies on genetic variability of lactation curve traits for Karan Fries cows [Ph.D. thesis], N.D.R.I. Deemed University Karnal India, 2010.

[19] V. Dongre, R. V. Gandhi, and A. Singh, "Comparison of different lactation curve models in Sahiwal cows," Turkish Journal of Veterinary and Animal Science, vol. 36, no. 6, pp. 723-726, 2012.

[20] K. D. A. Arik, Influence of some environmental factors, parity and calving weight on the lactation curve of indigenous Butana cattle [M.S. thesis], University of Juba, Juba, South Sudan, 2003.

[21] M. Tekerli, Z. Akinci, I. Dogan, and A. Akcan, "Factors affecting the shape of lactation curves of holstein cows from the Balikesir Province of Turkey," Journal of Dairy Science, vol. 83, no. 6, pp. 1381-1386, 2000.

[22] O. Kocak and B. Ekiz, "Comparison of different lactation curve models in Holstein cows raised on a farm in the South-Eastern Anatolia region," Archiv Tierzucht, vol. 51, no. 4, pp. 329-337, 2008. 
[23] T. M. Badri, M. Atta, T. Mohamed, and K. A. Ibrahim, "Genetic and non-genetic factors affecting lactation curve components of a Sudanese Butana dairy herd," Research Opinions in Animal \& Veterinary Sciences, vol. 1, no. 4, pp. 193-197, 2011.

[24] J. R. Gloria, J. A. G. Bergmann, C. R. Quirino et al., "Environmental and genetic effects on the lactation curves of four genetic groups of crossbred Holstein-Zebu cows," Brazilian Journal of Animal Science, vol. 41, no. 11, pp. 2309-2315, 2012.

[25] A. Fredrik, Q. Olav, R. Olav, and T. G. Yrjo, "Mastitis and the shape of the lactation curve in Norwegian dairy cows," Journal of Dairy Research, vol. 78, pp. 23-31, 2011.

[26] T. L. Stanton, L. R. Jones, R. W. Everett, and S. D. Kachman, "Estimating milk, fat, and protein lactation curves with a test day model," Journal of Dairy Science, vol. 75, pp. 1691-1700, 1992.

[27] A. Cappio-Borlino, G. Pulina, and G. Rossi, "A non-linear modification of Wood's equation fitted to lactation curves of Sardinian dairy ewes," Small Ruminant Research, vol. 18, pp. 7579, 1992.

[28] B. Portolano, F. Spatafora, G. Bono et al., "Application of the Wood model to lactation curves of Comisana sheep," Small Ruminant Research, vol. 24, no. 1, pp. 7-13, 1997.

[29] N. Friggens, G. Emmans, and R. Veerkamp, "On the use of simple ratios between lactation curve coefficients to describe parity effects on milk production," Livestock Production Science, vol. 62, no. 1, pp. 1-13, 1999.

[30] A. Kominakis, E. Rogdakis, and K. Koutsotolis, "Genetic aspects of persistency of milk yield in Boutsico dairy sheep," AsianAustralasian Journal of Animal Science, vol. 15, pp. 315-320, 2002.

[31] C. Dimauro, G. Catillo, N. Bacciu, and N. P. P. Macciotta, "Fit of different linear models to the lactation curve of Italian water buffalo," Italian Journal of Animal Science, vol. 4, pp. 22-24, 2005.

[32] G. Pulina, A. Nudda, N. P. P. Macciotta, G. Battacone, S. Fancellu, and C. Patta, "Non-nutritional strategies to improve lactation persistency in dairy ewes," in Proceedings of the 11th Annual Great Lakes Dairy Sheep Symposium, pp. 38-68, University of Wisconsin-Madison, Burlington, Vt, USA, 2005.

[33] A. A. Fadlemoula, I. A. Yousif, and A. M. Abu Nikhaila, "Lactation curve and persistency of crossbred dairy cows in the Sudan," Journal of Applied Science and Research, vol. 3, no. 10, pp. 1127-1133, 2007.

[34] B. K. Ahunu and J. D. Kabuga, "A study of the gamma function for describing Friesian lactation records in Ghana," Bulletin of Animal Health and Production Africa, vol. 42, pp. 147-152, 1994.

[35] T. R. Batra, "Comparison of two mathematical models in fitting lactation curves for pureline and crossline dairy cows," Canadian Journal of Animal Science, vol. 66, pp. 405-414, 1986.

[36] D. Vilas, Modeling lactation curve for sire evaluation in sahiwal cattle [Ph.D. thesis], National Dairy Research Institute (Deemed University), Karnal, India, 2012.

[37] J. C. M. Dekkers, J. H. Ten Haag, and A. Weersink, "Economic aspects of persistency of lactation in dairy cattle," Livestock Production Science, vol. 53, pp. 237-252, 1998.

[38] V. A. Capuco, D. L. Wood, R. L. Baldwin, K. R. Mcleod, and M. J. Paape, "Mammary cell number, proliferation, and apoptosis during a bovine lactation: relation to milk production and effect of ST,' Journal of Dairy Science, vol. 84, pp. 2177-2187, 2001.

[39] G. Catillo, N. P. P. Macciotta, A. Carretta, and A. CappioBorlino, "Effects of age and calving season on lactation curves of milk production traits in Italian water buffaloes," Journal of Dairy Science, vol. 85, no. 5, pp. 1298-1306, 2002.
[40] A. Kaygisız and H. A. Dergisi, "Comparison of lactation curve traits in Simmental and Brown Swiss cattle raised on the Altindere State Farm," Hayvancılık Araștirma Dergisi, vol. 7, no. 1, pp. 25-30, 1997.

[41] A. Kaygisız, Y. Vanll, I. Yılmaz, and H. Üretim, "A study on lactation curve traits of brown cattle," Journal of Animal Production, vol. 44, pp. 69-80, 2003.

[42] A. P. Cervantes, L. Fernández, and C. P. Ponce, "Characterization of lactation curves in production and major components of milk in different breeds and crosses in Mexican tropical conditions," Review of Cuba Sal. Animal, vol. 28, no. 2, pp. 90 95, 2006.

[43] I. Yilmaz, E. Eyduran, A. Kaygisiz, and K. Javed, "Estimates of genetic parameters for lactation shape parameters with multivariate statistical technique in Brown Swiss cattle," International Journal of Agriculture and Biology, vol. 13, pp. 174-178, 2011.

[44] J. Solkner and W. Fuchs, "A comparison of different measures of persistency with special respect to variation of test-day milk yields," Livestock Production Science, vol. 16, pp. 305-319, 1987.

[45] T. A. Ferris, I. L. Mao, and C. R. Anderson, "Selecting for lactation curve and milk yield in dairy cattle," Journal of Dairy Science, vol. 68, pp. 1438-1448, 1985.

[46] F. E. Madalena, M. L. Martinez, and A. F. Freitas, "Lactation curves of Holstein-Friesian and Holstein-Friesian cross Gir cows," Animal Production, vol. 29, pp. 101-107, 1979. 

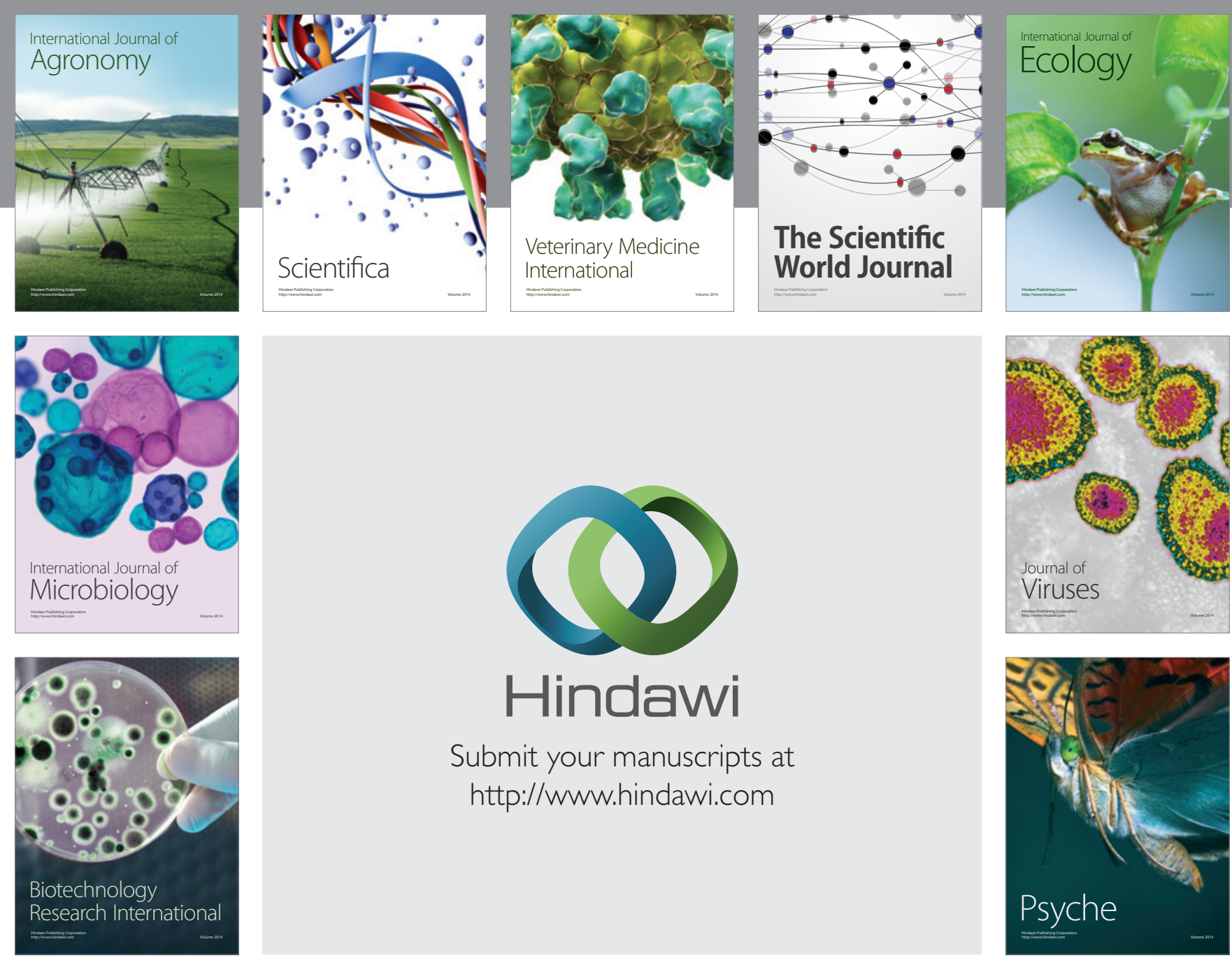

Submit your manuscripts at http://www.hindawi.com
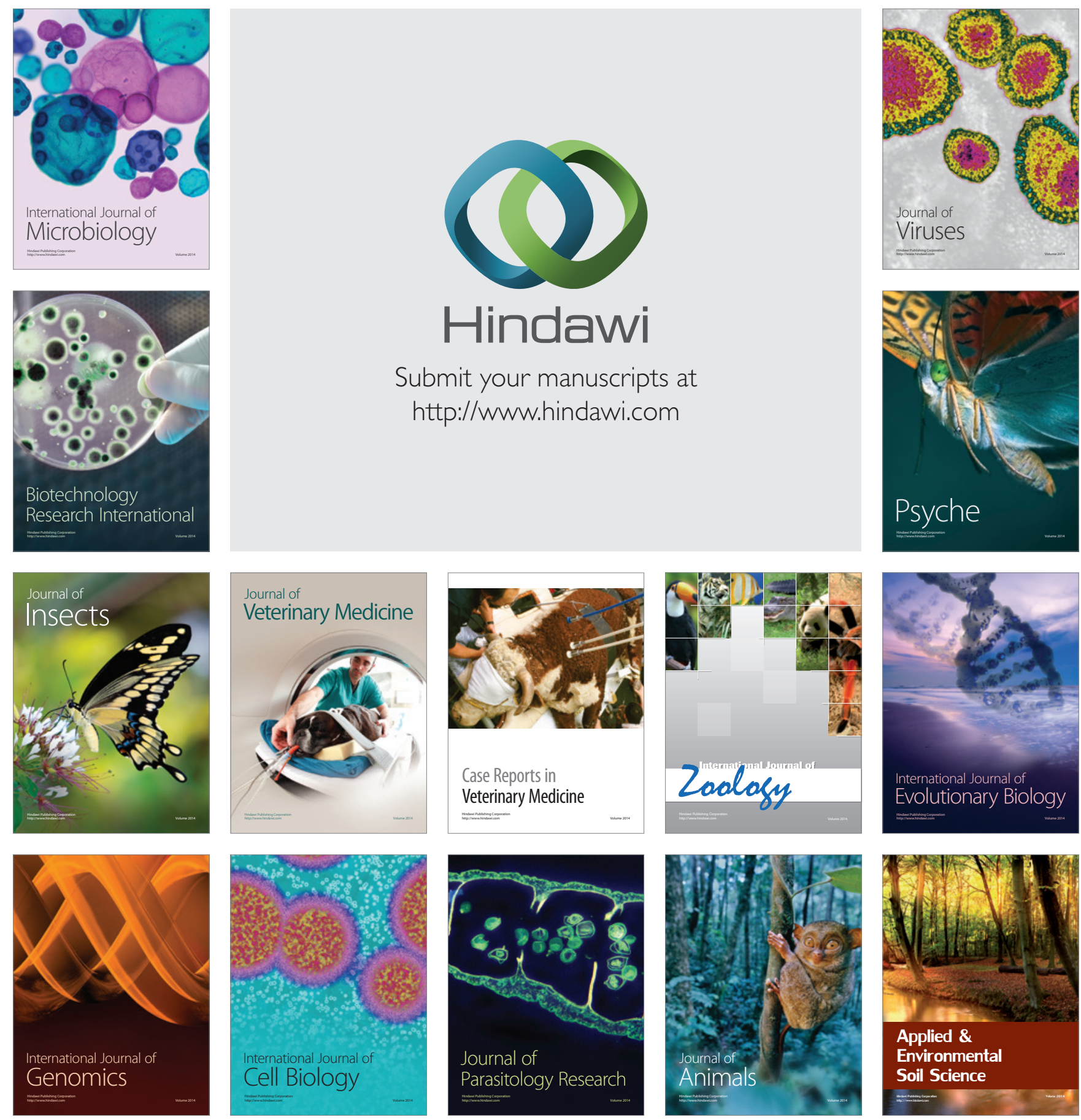